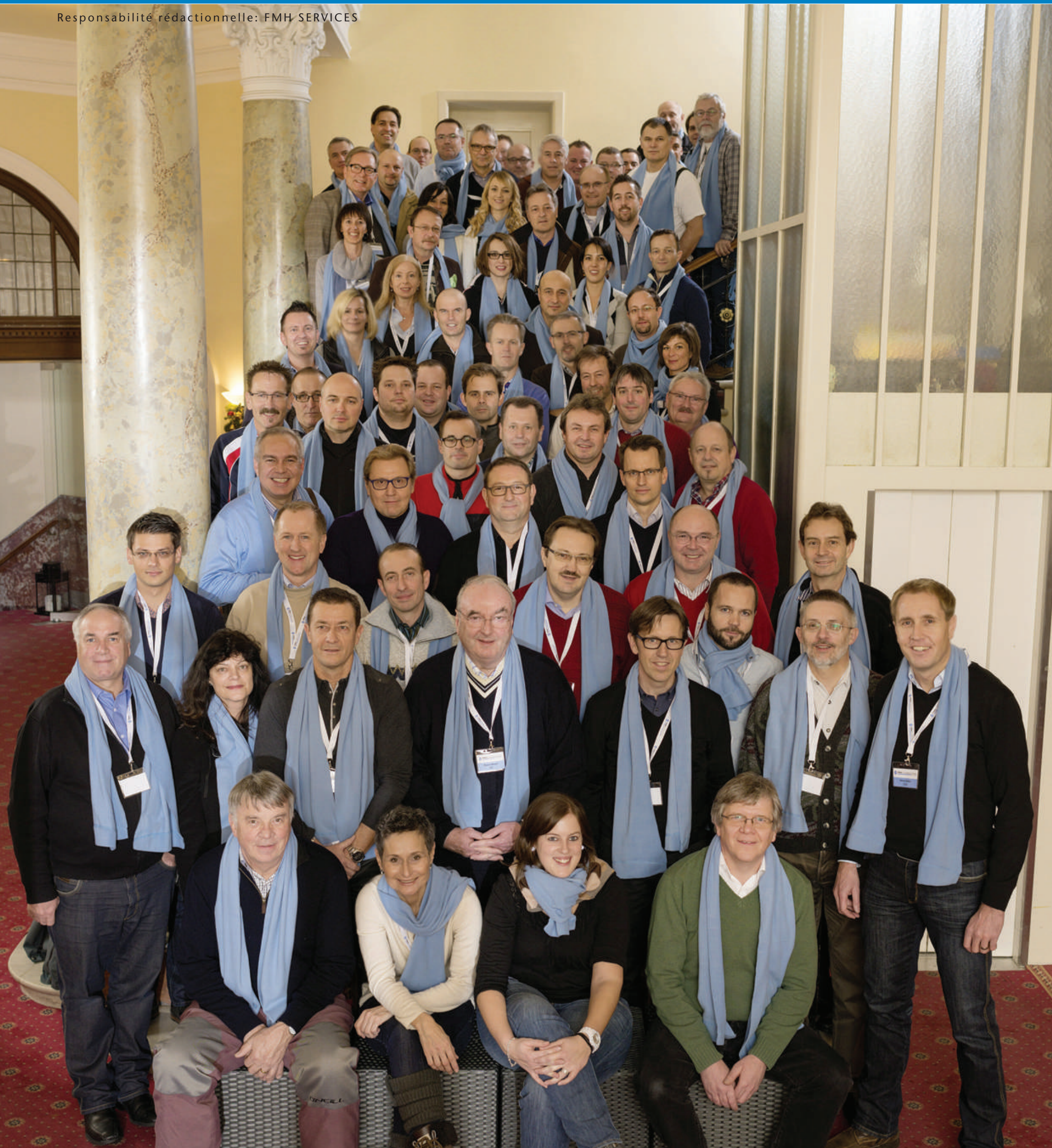

Frohe Festtage und ein glückliches neves Jahr!

Joyeuses fêtes et une excellente année 2015!

Buone feste ed un felice anno nuovo!

\section{F'FMH SERVICES}

$\frac{\stackrel{+}{N}}{\frac{n}{n}}$

FM7t Services Genossenschaft Burghöhe 1, 6208 Oberkirch

Tel. 0419250077 - Fax 0419210586

mail@fmhservices.ch - www.fmhservices.ch 